\title{
Effect of Market Value Ratios on Stock Return The Islamic Stock Exchange
}

\author{
Irma Christiana $^{1}$, Masta Sembiring ${ }^{2}$, Nurwani $^{3}$ and Hastina Febriaty ${ }^{4}$ \\ \{irmachristiana@umsu.ac.id ${ }^{1}$ \} \\ 1,2,3,4 University of Muhammadiyah Sumatera Utara, Jalan Kapten Mukhtar Basri No. 3 Medan, \\ Indonesia
}

\begin{abstract}
The purpose of this study was to test the influence of variable PER and PBVR against return stock Jakarta Islamic Index. Sampling by using purposive sampling technique, obtained samples as many as 8 companies that entered in the stock Jakarta Islamic Index during the period 2014-2017. Data analysis techniques using multiple linear regression. Hypothesis testing using the t-test statistics to partially and simultaneously use the F-test significant level of 5\%. Research results either partially or simultaneous shows that PER and PBVR has no effect against the return of the stock. For the ability of prediction of PER and PBVR against stock return of $12 \%$, the remaining $88 \%$ other factors influenced.
\end{abstract}

Keywords: Price Earning Ratio, Price to Book Value Ratio, Return Saham

\section{Introduction}

Investors investing in a company, aims to benefit from its investments and rights of ownership in the company. And the main thing is to maximize the wealth of the shareholders and maximize the value of the company at this time many investors who invest via the stock market.

Stock market is a platform where buyers and sellers reach out to maximize their utility. In order to properly transact, they meanly follow the prices of securities. However, the prices depend on many economic and political fundamentals; hence, many theories have been developed by economics to examine the behavior of stock prices (ÖZTÜRK et al., 2018).

The financial performance of the company that became the investment objective, should first be analyzed by the investors. Because of that investment was an uncertainty, investment with lower uncertainty (risk) tend to be large uncertainty compared with investments (Auret and Sinclaire, 2017). According to (Budiman, 2012) " Financial ratio analysis is not only used to know the strengths and weaknesses of companies in the field of finance but can also be used as an early warning system to deteriorate the company's financial condition ".

The indicators used to measure the success of the company, especially for public company (went public), namely by looking at the return on stocks (return of stock). According to (Hartono, 2013) "return of stocks is a result from investments". While according to Husnan (2015) "a good rate of return shows the good performance of the company. If the company's ability to generate profits increase, then stock prices will also increase "8. This means that the higher the return, the higher the risk. And if investors want low risk, then the return paid low. Obtain the maximum return is an expectation for all investors, so that it can be realized if done the analysis to find out the factors that affect the stock return.

Obtain the maximum return is an expectation for all investors, so that it can be realized if done the analysis to find out the factors that affect the stock return. 
Ratio PER and PBV against return company stock was chosen because it reflects the market's valuation against the stock and dividend growth to be an indicator. According to Elleuch (2009) "the ratio price earning ratio defined as stock price comparison between a listed company with an earnings per share". Ratio PER and PBV against return company stock was chosen because it reflects the market's valuation against the stock and dividend growth to be an indicator. The speed of the return on investment is often associated with a price earnings ratio of small value, the price earning ratio then a faster return on investment.

Price to Book Value (PBV), the ratio that compares the stock price with the price of the book. A good PBV value is more than one, which means that the price of shares sold in the market is higher than the value issued by the company. The higher the PBV value will lead to an increase in the stock price. This is because the stock price of a company continues to increase compared with the book value of the company (Bratamanggala, 2018). A higher stock price is something interesting for investors to buy them, because profit increase from the sale of shares.

Since its establishment, investment in Islamic stocks has experienced remarkable growth. At the end of 2002, there were 105 Islamic equity funds worth approximately US\$5 billion with 48 percent located in the Middle East, 30 percent in Europe and North America, and 22 percent in Asia (KR and $\mathrm{Fu}, 2014$ ). A Shariah Index is an index of companies, which are compliant with the Shariah law. of the value of a section of the stock market, which deals with socially responsible investment products. Worldwide, Shariah indices are created on the foundation of an existing or an underlying index, whose constituents have been screened for compliance by a board, called Shariah board, which is well versed in the principles of the Shariah (Siddiqui and Praveen, ).

The object of this research is a stock included in the Jakarta Islamic Index on the grounds that the Jakarta Islamic Index can be used as a measure of performance in select shares in accordance with halal or Shariah-compliant, contains no elements and structures ribawi the company's capital is not the majority comes from debt (Indonesia Stock Exchange, 2018). In addition what is empirically return resulting in the Group's shares also have similarities with financial ratios such as stocks in General. Because generally shares in the Jakarta Islamic Index have an unencumbered interest debt is high and has a healthy capital structure.

The following are the stock return data from 8 companies that entered in the stock Jakarta Islamic Index during the period of 2014-2017 can be seen in table 1

From table 1 it can be seen that the return of the shares showed a fluctuating trend during the period of observation 2014-2017, even by the year 2015 the stock return is negative. This is due to the influence of the global economy, Greece's debt crisis, the policy of raising interest rates by the Central Bank of America as well as the condition of the stock market of China. While domestic factors of decrease in the value of the JCI of $12.58 \%$ through the year 2015, as well as the decline of Islamic mutual fund-run funds caused a negative stock return (Kontan.co.id, 2016). While in the year 2016 return stocks rise high enough for the year 2015, this is due to the existence of a macro economic condition improvement as well as more and more investors are interested and started to turn to the Shariah-compliant products. 
Tabel 1. Stock Return

\begin{tabular}{|c|c|c|c|c|c|}
\hline \multicolumn{2}{|c|}{$\mathbf{N}$} & \multicolumn{4}{|c|}{ Year } \\
\hline \multirow[t]{2}{*}{ o. } & Code & 2 & 20 & 2 & 2 \\
\hline & & 014 & 15 & 016 & 017 \\
\hline \multirow[b]{2}{*}{$\dot{\bullet}$} & $\mathrm{A}$ & - & - & 2 & 0 . \\
\hline & DRO & 0.05 & 0.50 & .29 & 10 \\
\hline \multirow[t]{2}{*}{ 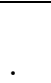 } & AS & 0 & - & 0 & 0 . \\
\hline & II & .09 & 0.19 & .38 & 003 \\
\hline \multirow{2}{*}{. } & BS & 0 & - & - & - \\
\hline & $\mathrm{DE}$ & .40 & 0.003 & 0.02 & 0.03 \\
\hline \multirow[t]{2}{*}{ - } & IN & 0 & - & 0 & - \\
\hline & DF & .02 & 0.23 & .53 & 0.04 \\
\hline & PG & 0 & - & - & - \\
\hline & AS & .34 & 0.54 & 0.02 & 0.35 \\
\hline \multirow{2}{*}{. } & U & - & - & 0 & 0 . \\
\hline & NTR & 0.09 & 0.02 & .25 & 67 \\
\hline \multirow{2}{*}{. } & $\mathrm{U}$ & 0 & 0. & 0 & 0 . \\
\hline & NVR & .24 & 15 & .05 & 44 \\
\hline \multirow{2}{*}{. } & WI & 1 & - & - & - \\
\hline & KA & .33 & 0.39 & 0.11 & 0.34 \\
\hline \multirow{2}{*}{\multicolumn{2}{|c|}{ Average }} & 2 & - & 3 & 0 . \\
\hline & & .28 & 1.72 & .35 & 45 \\
\hline
\end{tabular}

This research was conducted to find out the influence of PER and PBVR against the return of shares either partially or simultaneously, as consideration will be a condition of the company before investing, investors as well as to protect investors in order not to wrong decision to invest which can cause losses.

\section{Research Methods}

This research uses the associative approach as one part of quantitative research. This type of research is quantitative research using numerical data, in the form of a combined annual data between data according to population research period research amounted to 30 companies in Jakarta Islamic Index shares on the Indonesia stock exchange on the period of 2014-2017.

The sample was selected using a purposive sampling method, i.e. companies that meet the following qualifications: (1) the shares included in the Jakarta Islamic Index 2014-2017 period of the Indonesia stock exchange. (2) financial statements published during the period of observations that have been audited. (3) the Available data of financial statements that are required during a period of research. So the elected sample company as much as the company's 8th sample data and as many as 32 .

This study uses secondary data types. Engineering data collection using the technique of documentation, data obtained by taking the stock data is included in the Jakarta Islamic Index. Technique of data analysis using regression liner compounds to test the influence of PER and PBVR against the return of shares either partially or simultaneous. 


\section{Results And Discussion}

\subsection{Results}

Description of statistics showed an average of each variable has a positive figure by the number of observations $(\mathrm{N})$ data there is 32 . During the period of observation, variable PER used the resulting profit estimate is equivalent to the price of its shares, with the average value $=20,0138 \mathrm{x}$, and the standard deviation $=13.70189$.

PBVR is a variable that explains how much the market takes into account the book value of shares. The greater this ratio means investors believe in the financial condition of the company. On average PBVR $=8.9272 \mathrm{x}$ and standard deviation $=9.67591$. The results of this study indicate the average return $=2.9687$ and standard deviation $=0.53801$. This means that the average company experiences an increase in stock returns of 14,52520.

So that the test results are unbiased and efficient, then the multiple regression model of qualified test assumptions should be classic, which includes a test of normality, multicollinearity, and heterokedastisitas.

Normality test results with the P-chart approach Plot shows that the data have a normal distribution, where the point spread is around the axis of the diagonal of the graph.

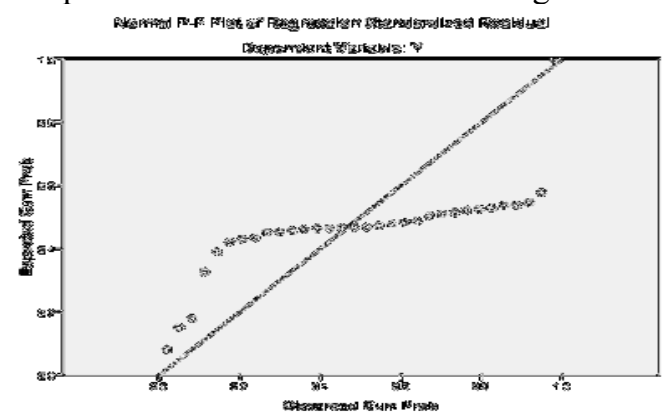

Fig.1. Normality Test

Multicolinearity test results can be seen in table 2, which shows that the value of the PER and PBVR VIF $=4.196$ does not exceed 10, so there happen multicolinearity.

Tabel 2. Multikolinearity Test

\begin{tabular}{rrr}
\hline \multirow{2}{*}{ Model } & \multicolumn{2}{c}{ Collinearity Statistics } \\
\cline { 2 - 3 } & Tolerance & VIF \\
\hline 1 & & \\
(Constant) & & 4.196 \\
\hline PER & .238 & 4.196 \\
\hline PBV & .238 & \\
\hline
\end{tabular}

The next heterocedasticity test is performed can be seen in figure 2 using a Scatterplot graph showing the spread of random dots above or below the 0 on the $\mathrm{Y}$ axis, meaning that it does not happen heterocedasticity. 


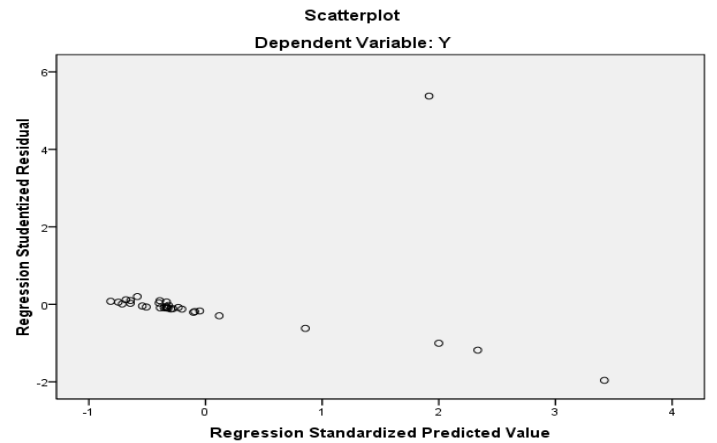

Fig.2. Multikolineritas Test

Further analysis with multiple linear regression, the results show: $\mathrm{Y}=-2.337+0,214 \mathrm{X} 1+$ $0,115 \mathrm{X} 2+\mathrm{e}$. The explanation is as follows:

1. Constants of 2.337 PER variable and then when PBVR is assumed to be zero, then the value of the stock return is registration -2.337 .

2. PER has regression coefficients $=0.214$ means that's every one unit change on PER then return up by 0.214 assuming other variables are assumed to be fixed.

3. PBVR has regression coefficient $=0.115$ means that every one unit change on PBVR then return up by 0.115 assuming other variables are assumed to be fixed.

The results of hypothesis testing the effect of PER and PBVR on stock returns can be seen in table 3 and table 4 below:

Based on table 3 and table 4, results of hypothesis testing showed the following:

1. Hypothesis 1, PER positive and significant effect against the return of shares. The test results showed the value of sig. $=0.565$ PER of above the value of $\alpha=0.05$ means that PER no effect against the return of shares.

Tabel 3. $t$ Test

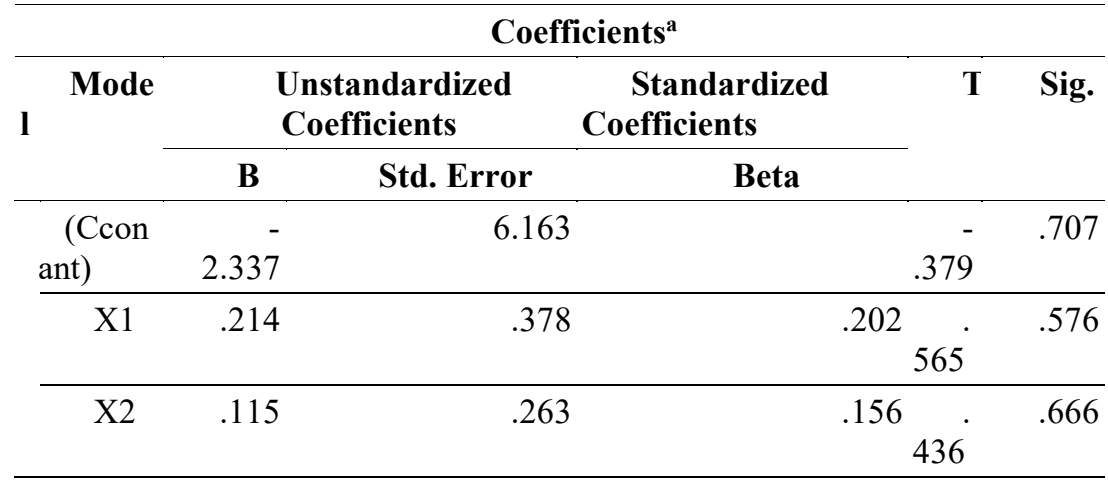

Tabel 4. F Test

\begin{tabular}{lccccc}
\hline \multicolumn{5}{c}{ ANOVA $^{\mathbf{b}}$} \\
\hline Model & Sum of & d & Mean & F & Si \\
& Squares & f & Square & & g. \\
\hline
\end{tabular}




\begin{tabular}{ccccrr}
\hline $\begin{array}{c}\text { Regre } \\
\text { sion }\end{array}$ & 782.911 & 2 & 391.455 & 1. & 1 \\
\hline Resid & 5757.516 & 2 & 198.535 & & \\
ual & & 9 & & \\
\hline Total & 6540.426 & 3 & & \\
& & 1 & & \\
\hline
\end{tabular}

2. Hypothesis 2, PBVR positive and significant effect against the return of shares. The test results showed the value of sig. $=0.436$ PBVR of above the value of $\alpha=0.05$ means that PBVR no effect against the return of shares

3. Hypothesis 3, PER and PBVR positive and significant effect against the return of shares. The results of testing simultaneously show the value of sig. PER and PBVR $=0.157$, above the $\alpha=0.05$ means that PER and PBVR has no effect against the return of shares.

To see the percentage of independent variable influences the dependent variable on the table against 5

Tabel 5. Coefficient Of Determination

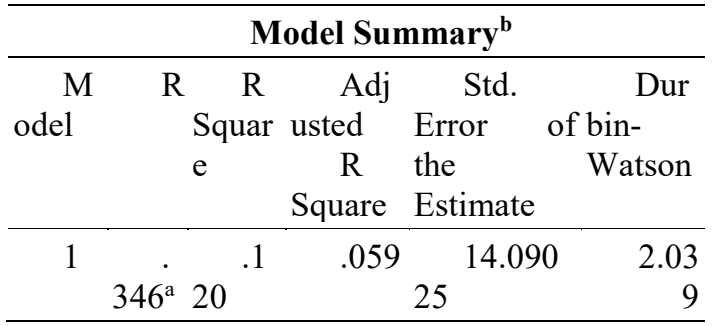

a. Predictors: (Constant), X2, X1

b. Dependent Variable: Y

From table 5 above is the magnitude of the influence of variables independent of the dependent variable of 0.120 or $12 \%$, and the remaining $88 \%$ is affected by other variables. The correlation or relationship between the dependent variable independent variable, shown the correlation coefficient value of $(\mathrm{R})$ of 0.346 or $34.6 \%$.

\subsection{Discussion}

Price earning ratio (PER) and the price to book value ratio (PBVR) is the ratio of market value that describes the assessment market and prospects to the company concerned. If the value of the price earning ratio and price to book value ratio, high reflects the high valuation of the market or the investors against the company. If the value of the price earning ratio and price to book value ratio is low means the assessment of the market or the investors against the company law.

Test results and analysis of the influence of data PER return against stocks partially found that the return of shares not affected by. PER, the value of sig. $=0.565$ PER above a value of $\alpha$ $=0.05$. PER no effect caused by various factors, such as political instability, social, and economic impact is Indonesia, the prevailing share price is affected by the supply and demand for shares, not based on the actual information about the condition of the company. These results are in accordance with the ('Jurnal Inter Fix', no date), (Carlo, 2014). But in contrast to 
the results of research Wuldani Sodikin (2016), (Bratamanggala, 2018) that concluded that the return of shares affected by PER.

The PBVR from test results and analysis of the data shows the return of the shares not affected by PBVR, indicated by sign value. price to book value ratio of 0.436 above the value of $\alpha=0.05$. PBVR has no effect against the return of shares because investors would not buy shares at a low price because of the impact on the stock price and the repayment rate will decrease in the future. This result is in accordance with the research by (Sujana and Sinarwati, 2014), (Budiman, 2012). But different studies with research conducted (Martani, Mulyono and Khairurizka, 2009), Penman, Stephen H., et all (2007) and (Bratamanggala, 2018) which concluded that PBVR effect on stock return.

Simultaneously, PER and PBVR has no effect against the return of stocks, because the value of sig. of 0.157 above the value of $\alpha=0.05$. This means that during the period of 20142017 investors in investment decision-making not based on PER and PBVR when buying shares, however are more considerate of other things such as more focus on the profitability of a company for profit (Penelitian et al., 2017).

The influence of PER and PBVR against the return of Sharia Jakarta Islamic Index shares proportionally of 0.120 or $12 \%$ and the remaining $88 \%$ or 0.88 , meaning that the price earning ratio (PER) and the price to book value (PBVR) has a lower contribution in improving the return the stock, because there are still financial ratios and other factors - factors that exert influence on stock return.

\section{Conclusion}

Conclusion the results of the research and the discussion is (1) not to return PER share. (2) partially PBVR has no effect against the return of the stock. (3) simultaneous PER and PBVR has no effect against the return of shares.

\section{References}

[1] Auret, C. J. and Sinclaire, R. A. (2017) 'Book-to-market ratio and returns on the JSE Book-to-market ratio and returns on the JSE', 3523(March).

[2] Bratamanggala, R. (2018) 'The factors affecting board stock price of Lq45 stock exchange 2012-2016: Case of Indonesia', European Research Studies Journal, 21(1), pp. 115-124. doi: 10.1109/ICRA.2015.7139505.

[3] Budiman, S. (2012) 'Analysis of Consumer Attitudes to Purchase Intentions of Counterfeiting Bag Product in Indonesia', International Journal of Management, Economics and Social Sciences, 1(1), pp. 1-12. doi: 10.24327/IJRSR.

[4] Carlo, M. A. (2014) 'PENGARUH RETURN ON EQUITY, DIVIDEND PAYOUT RATIO, DAN PRICE TO EARNINGS RATIO PADA RETURN SAHAM', 1, pp. 151164. 'Jurnal Inter Fix' (no date).

[5] KR, K. R. and Fu, M. (2014) 'Does Shariah Compliant Stocks Perform Better than the Conventional Stocks? A Comparative Study Stocks Listed on the Australian Stock Exchange', Asian Journal of Finance \& Accounting, 6(2), p. 155. doi: 10.5296/ajfa.v6i2.6072.

[6] Martani, D., Mulyono and Khairurizka, R. (2009) 'The effect of financial ratios, firm size, and cash flow from operating activities in the interim report to the stock return', Serial Chinese Business Review, 8(6), pp. 1537-1506.

[7] ÖZTÜRK, M. B. et al. (2018) 'Takvim Anomalilerinin Hisse Getirileri ve Varyansı Üzerindeki Etkisi: Türkiye Hisse Senedi Piyasası Üzerinde Bir Çalışma', Ömer 
Halisdemir Üniversitesi Iktisadi ve İdari Bilimler Fakültesi Dergisi, 11(1), p. 221. doi: 10.25287/ohuiibf.381031.

[8] Penelitian, L. et al. (2017) 'Jurnal Studi Akuntansi \& Keuangan', 1, pp. 11-20. doi: 10.5281/zenodo.1064186.

[9] Siddiqui, S. and Praveen, S. (no date) 'Modelling the Return of Shariah with Underlying Indices of National Stock Exchange of India : A Case of 3SLS and GMM Estimation'.

[10] Sujana, E. and Sinarwati, N. K. (2014) 'PENGARUH PRICE TO BOOK VALUE ( PBV ), PRICE EARNING RATIO ( PER ) DAN DEBT TO EQUITY RATIO ( DER ) TERHADAP RETURN SAHAM PADA INDUSTRI REAL ESTATE DAN PROPERTY YANG TERDAFTAR DI BURSA EFEK INDONESIA PERIODE 2009 2013', 1(1). 